\title{
Quantitative Analysis of Spatio-Temporal Evolution of Ecosystem Structure in the Water-Land Interaction Area of Nansi Lake Based on Remote Sensing Technology
}

\author{
Yin Ma ${ }^{1}$, Xinqi Zheng ${ }^{1,2 *}$, Jiantao Liu ${ }^{3}$, Wenchao Liu ${ }^{4}$, Fei Xiao ${ }^{4}$ \\ ${ }^{1}$ School of Information Engineering, China University of Geosciences, Beijing, China \\ ${ }^{2}$ Technology Innovation Center for Territory Spatial Big-Data, MNR of China, Beijing, China \\ ${ }^{3}$ School of Surveying and Geo-Informatics, Shandong Jianzhu University, Jinan, China \\ ${ }^{4}$ Information Center of Ministry of Natural Resources of the People's Republic of China, Beijing, China
}

Received: 9 November 2020

Accepted: 8 March 2021

\begin{abstract}
Monitoring ecological environment with remote sensing technology is an effective means of environmental management and sustainable development. Based on Landsat image data and field survey data, this paper used the unweighted voting multi-classifier ensemble method to extract the ecosystem cover data of the water-land interaction area of Nansi Lake from 1987 to 2017, and analyzed the evolution characteristics of the ecosystem structure with the help of the transfer matrix and landscape pattern index. The results showed: (1) The accuracy of multi-classifier ensemble was higher than that of single classifier, with a maximum improvement of $4.17 \%$. (2) In 2006, the change inflection point of ecosystem structure appeared in the study area, which showed that the trend of increase and decrease of ecosystem area changed, and the degree of landscape fragmentation was the lowest. The structure and type transfer of the ecosystem in the study area showed the characteristics of "ring" distribution, and the distribution and transfer of ecosystem at the junction of land and water and land were more complex. (3) Human activities under the intervention of China's policies, climate change and ecosystem self-regulation were the main driving factors for the change of ecosystem structure in the study area. This study provided technical methods for the further exploration of the ecosystem, and provided constructive guidance for the protection and sustainable development of ecological environment.
\end{abstract}

Keywords: remote sensing information extraction, multi-classifier ensemble, ecosystem structure, water-land interaction area

*e-mail: zhengxq@cugb.edu.cn 


\section{Introduction}

With the development of economy and the growth of population, the ecological environment problem has become a key problem to be solved in the world, and the stability of ecosystem structure is an important manifestation of ecological environment change [1-4]. In the international community, various ecosystems were monitored, evaluated and restored through the formulation of laws and regulations, the establishment of protection organizations and the implementation of special projects, so as to strengthen the stability of ecosystems and improve the quality of ecological environment [4-6]. In recent years, the Chinese government strengthened the protection of ecosystems through the establishment of nature reserves and the demarcation of ecological protection redline [7-9]. It also required the use of "remote sensing" technology, including the release of "ecological environment remote sensing monitoring technology" program and the establishment of Provincial Ecological Environment Remote Sensing Monitoring Center, to strengthen the monitoring, evaluation and early warning of ecosystem and ecological environment [10]. At the same time, scholars also used remote sensing (RS) and geographic information system (GIS) and other technologies to monitor and analyze the ecological [11] and environmental problems in various research areas such as coal mining areas [12], cities [13], water areas [14] and so on.

With the deepening understanding of the ecological environment problem and its regularity, the study of ecological environmental monitoring is not only limited to the quantitative change and composition analysis of certain pollutants, but also tends to discuss the problems of ecological balance, stability, evaluation and sustainable development in the region. Therefore, the traditional data collection methods obviously cannot meet the current research needs $[15,16]$. In recent years, the rapidly developing remote sensing technology with advantages of large area synchronous observation, strong timeliness and periodicity has provided new insights and methods for ecological environment monitoring [16, 17]. Many scholars used random forest classification (RFC) [18], support vector machine (SVM) [19], artificial neural network (ANN) [20], k-nearest-neighbor(KNN) [21] and other single classifier to extract ecosystem information from remote sensing images and perform research and analysis. A small number of scholars attempted to explore methods such as fusing multiple data, selecting multiple features [22], improving single classifier [23, 24] and integrating double classifiers $[18,25]$ to improve the accuracy of ecosystem information extraction. By reviewing the literature, it is found that few scholars extracted the ecosystem cover by integrating multiple classifiers.

Nansi Lake is an important freshwater source in China and an ecological barrier between the south and the north. The balance of its ecosystem affects the smooth implementation of the eastern route of the South-to-North Water Diversion Project and the stability of the national ecological environment. In 2018, Nansi Lake wetland was listed as an international important wetland by the international wetland convention organization, which recognized the importance of its location and ecological service function from an international perspective, and also inspired us to strengthen the monitoring and protection of ecological environment of Nansi Lake. In recent years, many scholars studied the migration rate [26, 27], spatial distribution characteristics [28], pollution risk assessment [29-31] of heavy metal pollutants in the sediments of Nansi Lake. Numerous scholars explored and studied the ecological service function and land use pattern of Nansi Lake [32, 33], emphasizing the importance of its ecological environment. A few scholars studied and analyzed zooplankton community [34], the relationship between water pollution and economic development [35], antibiotics [36] and so on. To sum up, scholars ignored the research on the quantitative analysis of ecosystem structure in the longtime series of the water-land interaction area of Nansi Lake.

The paper performs some research in order to explore spatio-temporal evolution of ecosystem structure in the water-land interaction area of Nansi Lake and overcome the limitations of single classifier to extract ecosystem cover information from remote sensing images. More specifically, firstly, based on Landsat series of satellite images and field investigation data, the paper discusses the multi-classifier integration method to extract the ecosystem cover data of the water-land interaction area of Nansi Lake from 1987 to 2017. Secondly, the classification accuracy of multiclassifier integration and single classifier is verified and compared, and the evolution characteristics and driving factors of ecosystem structure in the study area are analyzed. Finally, the paper aims to provide some suggestions for the protection and restoration of ecological problems of Nansi Lake, and also put forward some enlightenments for the monitoring and management of ecological environment.

The content of the article is organized as follows. Section 2 introduces the research location, research data, multi-classifier ensemble and analysis methods. Section 3 analyses the results and discussion. Conclusions are shown in section 4 .

\section{Materials and Methods}

\section{Study Area}

Nansi Lake $\left(34^{\circ} 27^{\prime}-35^{\circ} 20^{\prime} \mathrm{N}, \quad 116^{\circ} 34^{\prime}-117^{\circ} 21^{\prime} \mathrm{E}\right)$ including Nanyang Lake, Dushan Lake, Zhaoyang Lake and Weishan Lake from northwest to southeast in strips is located at Weishan County, Jining City, Shandong Province, China. It is adjacent to Zaozhuang 


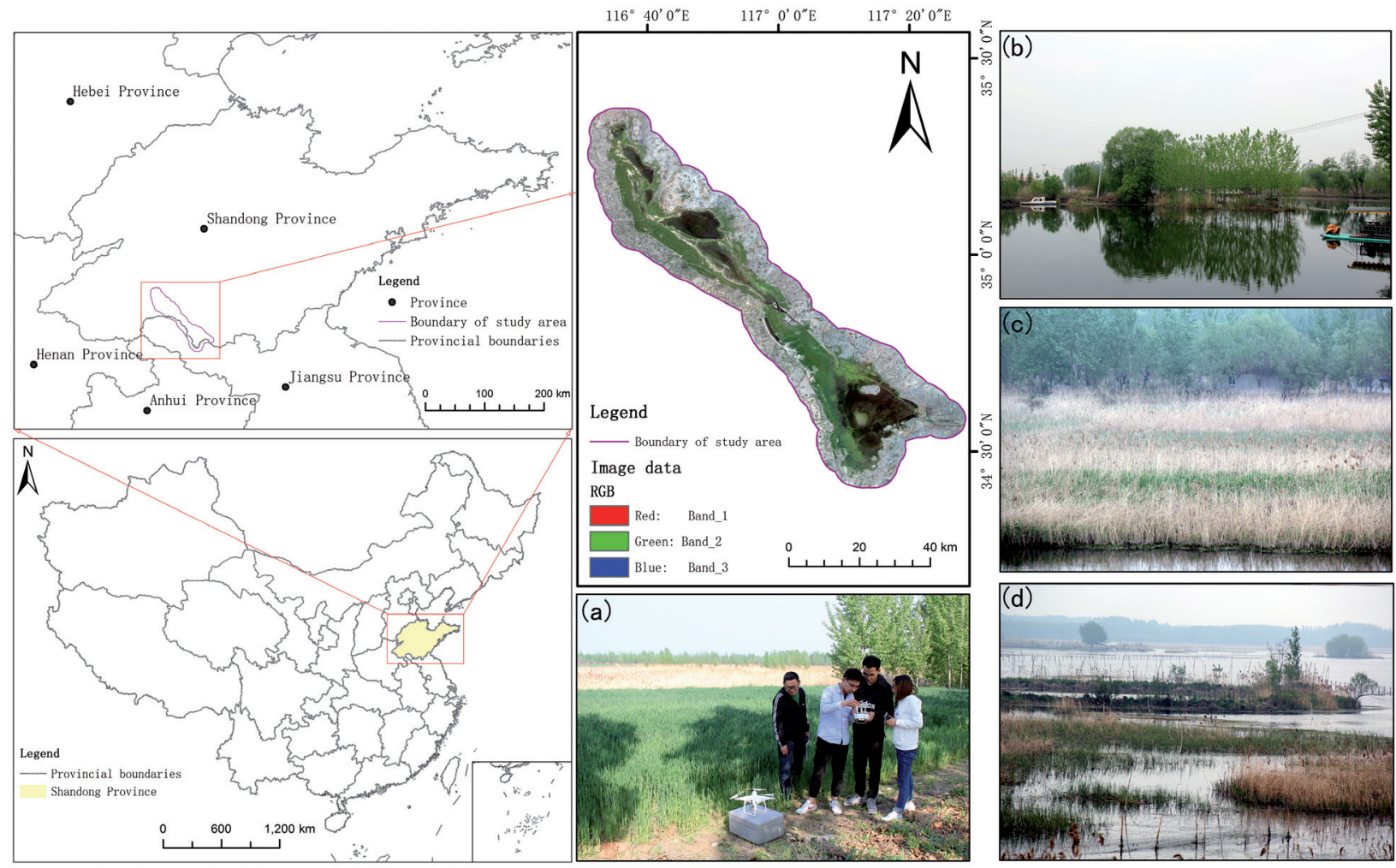

Fig. 1. Study area and field investigation picture.

City in Shandong Province and Xuzhou City in Jiangsu Province (Fig. 1). Nansi Lake with $125 \mathrm{~km}$ in length and $5-25 \mathrm{~km}$ in width is the largest freshwater lake in North China, and is also a large inland freshwater and grass lake wetland with the largest area, complete structure and good preservation in the north of Huai River $[15,33]$. The study area belongs to a warm temperate semi humid monsoon climate zone, with four distinct seasons, rain and heat at the same time, sufficient light, precipitation concentration and other characteristics. Due to its unique natural environment, there are 195 species of plants, 201 species of birds and 13 species of mammals [37]. As an important shipping "Golden Waterway" in Shandong and Jiangsu and the main storage hub of the eastern route of the South-to-North Water Diversion Project, it undertakes an important task for economic development.

In the paper, the study time series is long, and the water area of the water-land interaction area of Nansi Lake is obviously affected by precipitation, temperature and other external factors. In addition, the ecosystem has the characteristics of sustainability and openness. Therefore, the $5 \mathrm{~km}$ buffer zone is expanded on the basis of the Nansi Lake area to ensure the integrity of the study.

\section{Data Sources and Processing}

The paper obtains four different kinds of data, which are Landsat series satellite image data, field research data, statistical data and national policy documents.
The research period of the paper is from 1987 to 2017. Four periods of image data in 1987, 1997, 2006 and 2017 are selected as the main research data, which are from the international scientific data image website of Computer Network Information Center of Chinese Academy of Sciences (http://www.cnic.cas.cn/zcfw/sjfw/ gjkxsjjx/). The details are shown in Table 1 . In the study area, the surface cover in summer is more luxuriant, with obvious spectral and texture features, which is convenient for information extraction. Therefore, the imaging time of the selected images was in May or June. The cloud cover of the selected image is less, and the cloud on the image is outside the study area in 2017. The image is preprocessed for eliminating the error in the process of remote sensing image imaging in ENVI 5.3. Firstly, the band that is convenient to identify the features of the ground features is selected. Secondly, the DEM data is used to correct the image without control points. Then, the image is enhanced with spatial domain enhancement method. Finally, the image is clipped by the vector map of the study area. The image has stronger spectral separability, clear texture and obvious geometric features after image preprocessing, which plays an active role in the later sample data collection and information extraction.

The research team conducted field investigation in the water-land interaction area of Nansi Lake from April 14 to 16, 2019. The habitat status and ecosystem type characteristics of the study area were obtained and understood by classifying and collecting the survey data, which provided rich prior knowledge for the study 
Table 1. List of remote sensing image data in the study area.

\begin{tabular}{|c|c|c|c|c|c|c|}
\hline Satellite & Sensor & Imaging date & Resolution $(\mathrm{m})$ & Number of bands & Track line number & Cloud cover \\
\hline Landsat 5 & TM & 1987.06 .15 & 30 & 7 & P122R36 & $0.00 \%$ \\
\hline Landsat 5 & TM & 1997.05 .25 & 30 & 7 & P122R36 & $0.00 \%$ \\
\hline Landsat 5 & TM & 2006.05 .02 & 30 & 7 & P122R36 & $0.00 \%$ \\
\hline Landsat 8 & OLI & 2017.06 .17 & 30 & 9 & P122R36 & $0.46 \%$ \\
\hline
\end{tabular}

and reference for the selection of sample data. The habitat conditions in some areas of the study area are shown in Fig. 1(a-d).

Statistical data are from Shandong Provincial Bureau of Statistics and Jining Bureau of Statistics (http://tjj.shandong.gov.cn/; http://tjj.jining.gov.cn/), and some of them are from published academic papers. The national policy documents are mainly from the Ministry of Ecology and Environment of the People's Republic of China and management department of Nansi Lake.

\section{Research Methods}

\section{Multi-Classifier Ensemble}

After reviewing the relevant literatures [22, 24, 38], it is found that most scholars used SVM, RFC and ANN classifiers based on machine learning to extract remote sensing information of ecosystem cover [22, 38]. This kind of classifier can reflect the optimal characteristics of target features and establish a classification model with learning the sample data by itself, so as to achieve better classification results. The greatest advantage of SVM is that it can seek the optimal classification surface between different samples from small samples, but it is sensitive to the selection of parameters and kernel functions, and it is robustness [39, 40]. RFC has the advantages of high operational efficiency, good robustness, strong data compatibility and good at processing high-dimensional feature samples [41], but it is not friendly to small or low-dimensional samples data. ANN is a nonlinear dynamic machine learning classification method that simulates the operation of human brain neurons [42]. Its classification idea is more similar to that of manual interpretation, and its learning ability is also strong, but it cannot explain the classification process systematically. The three single classifiers have their own advantages and disadvantages, and the combination of them can complement each other and improve the classification accuracy.

The common algorithms of ensemble multi-classifier include voting method, evidence theory method, Bayesian average method and so on [43]. Voting method by defining voting rules according to prior knowledge to conduct a classified result vote is the most commonly used ensemble method, which is simple and easy to operate [44]. Dempster-Shafer evidence theory does not need prior knowledge, but it requires higher conditions of evidence and trust function [45]. Bayesian average method defines the "prior probability", and then revises the "prior probability" to make it close to the real voting result through each vote [46]. This study integrates the classification results of all classifiers under the guidance of prior knowledge, so the voting algorithm is selected. Moreover, the three single classifiers are all based on the idea of machine learning for image classification, and they have different characteristics, and the classification accuracy gap is small, so there is no hierarchy or weight relationship [22]. In summary, the "majority voting method" based on the idea that the minority is subordinate to the majority is selected to integrate the single classifier classification results without weighted voting. The ensemble is completed with band calculation tool in ENVI 5.3. From the pixel scale, there are five kinds of ensemble. This is presented in Fig. 2: a) If the classification results of the three single classifiers are the same, and the classification results will be output. (b-d) If the classification results of two single classifiers are the same, and the classification results of the third single classifier are different from the previous two classification results, the same result of the two single classifiers will be output as the final classification result. e) If the classification results of single classifier are different, and the classifier with the highest classification accuracy will be output. In this study, the classification results of SVM which has the highest classification accuracy will be output. Finally, the accuracy of the integrated classification results is analyzed.

\section{Analysis of Ecosystem Structure}

As time goes by, ecological system structure will change and transfer. The transfer matrix method is used to explore the characteristics of ecosystem structure change of water-land interaction area of Nansi Lake from 1987 to 2017. The ecosystem transfer matrix can reflect the changes of ecosystem area at the beginning and the end of the study, and also clearly describe the direction and evolution trend of ecosystem transfer $[47,48]$. The transfer matrix that proposed by Markov who is a mathematician in Russian is a mathematical expression of the number of conversion between different types of things. In geography research, transfer matrix is widely used in land use change analysis and Markov simulation analysis [48]. In this paper, the 


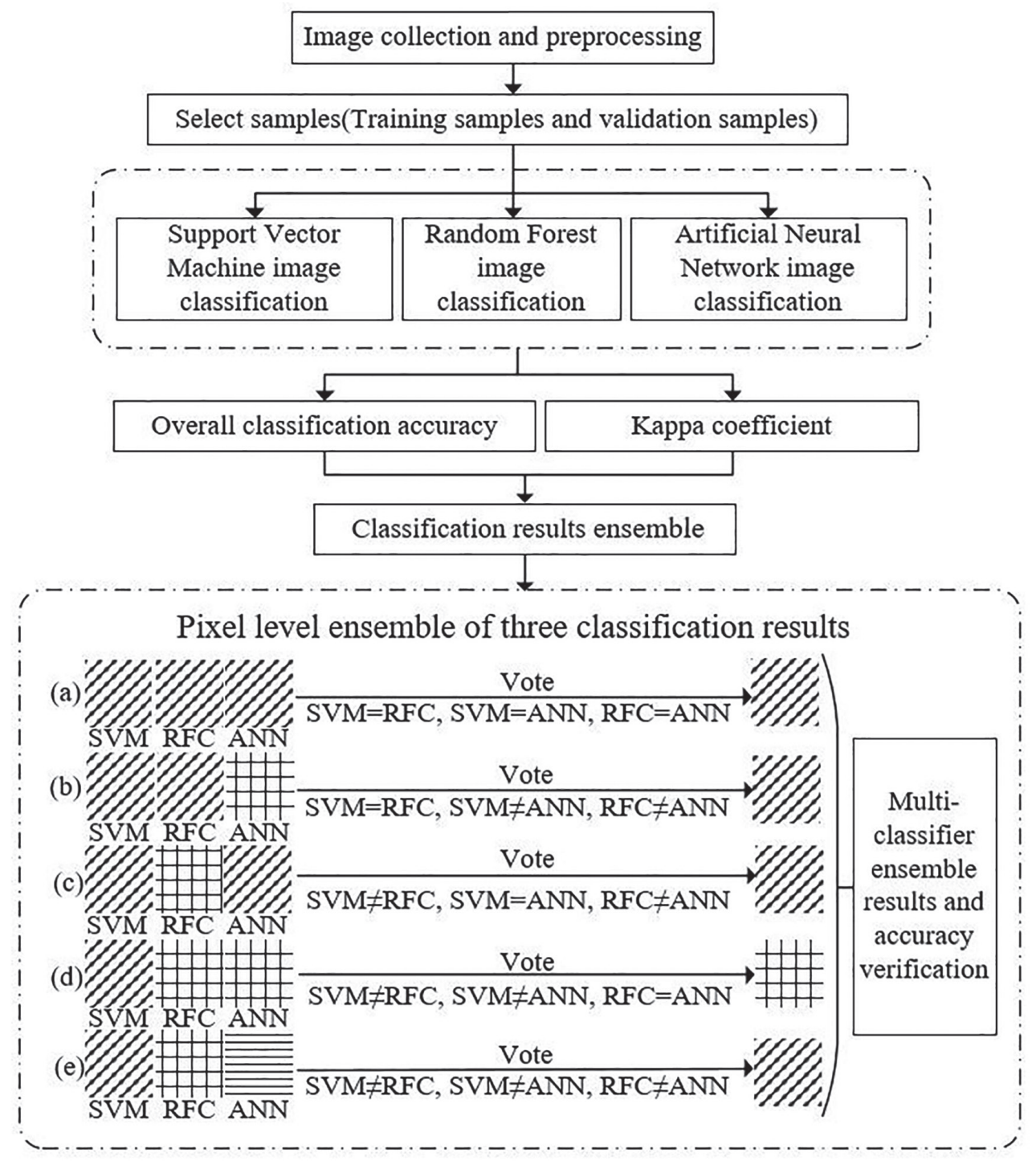

Fig. 2. Technical route of multi-classifier ensemble Note: (1) For the same pixel,“=”means that the classification results of two single classifiers are identical, " $\neq$ " means that the classification results of two single classifiers are different. (2) As shown in (e), if the classification results of single classifier are different, the classification results of SVM which has the highest classification accuracy will be output.

transfer matrix drawn by the intersect tool of ArcGIS 10.5 and excel tool is used to analyze the characteristics of ecosystem structure in the water-land interaction area of Nansi Lake. The mathematical expression of transfer matrices is as follows:

$$
\mathrm{S}_{\mathrm{ij}}=\left[\begin{array}{ccccc}
\mathrm{S}_{11} & \mathrm{~S}_{12} & \mathrm{~S}_{13} & \cdots & \mathrm{S}_{1 \mathrm{n}} \\
\mathrm{S}_{21} & \mathrm{~S}_{22} & \mathrm{~S}_{23} & \cdots & \mathrm{S}_{2 \mathrm{n}} \\
\mathrm{S}_{31} & \mathrm{~S}_{32} & \mathrm{~S}_{33} & \cdots & \mathrm{S}_{3 \mathrm{n}} \\
\vdots & \vdots & \vdots & \vdots & \vdots \\
\mathrm{S}_{\mathrm{n} 1} & \mathrm{~S}_{\mathrm{n} 2} & \mathrm{~S}_{\mathrm{n} 3} & \cdots & \mathrm{S}_{\mathrm{nn}}
\end{array}\right]
$$

Landscape scale research is a common study scale in ecology, and the spatio-temporal evolution of ecosystem structure will inevitably lead to changes in different landscape patches in the study area [49]. On the contrary, patch fragmentation can directly reflect the degree of ecosystem fragmentation and explain the self-regulation ability of ecosystem [50]. In order to explore the relationship between ecosystem evolution characteristics and fragmentation in the water-land interaction area of Nansi Lake, the patch density (PD) commonly used in landscape pattern index was used to describe the landscape fragmentation of the ecosystem in the study area. PD represents the number of patches per square kilometer. Large PD shows that landscape distribution is dispersed and complicated, thus breaking degree becomes higher, and smaller PD indicates that landscape distribution is concentrated and simple, thus the degree of fragmentation is lower [51]. The mathematical expression is as follows:

$$
P D=N / A
$$


PD stands for patch density. $\mathrm{N}$ is the total number of patches. $\mathrm{A}$ is the total area of the landscape $\left(\mathrm{km}^{2}\right)$.

\section{Results and Discussion}

\section{Accuracy Verification of Multi-Classifier Ensemble Classification Results}

Referring to the Ecosystem Classification Standard, the Convention on Wetlands, the Present Situation of Land Use Classification and the previous research experience and achievements, the ecosystem of the water-land interaction area of Nansi Lake is classified into three levels based on remote sensing image data, land-water interaction characteristics and field research results. The classification rules are shown in Table 2. The process of classification is divided into two steps. Firstly, the remote sensing interpretation marks of ecosystem in the study area are established according to the location, color, shape, texture and other characteristics of the target features. Secondly, the region of interest is created and samples are defined. In addition, the validation samples are selected by combining high-resolution Google Earth images and field survey results.

According to the multi-classifier ensemble method and the classification rules of the ecosystem in the study area proposed in this paper, the ecosystem cover information of the water-land interaction area of Nansi Lake in 1987, 1997, 2006 and 2017 is extracted and verified. As shown in Table 3, SVM has the highest classification accuracy among the three single classifiers.
The reason is that there are relatively few training samples in the study, and SVM is good at learning the classification features from small samples to derived better classification results. The classification accuracy of RFC is only second to that of SVM, which may be due to the small amount of data and simple structure of the original image and training samples, so it does not give full play to the advantages of RFC in dealing with high-dimensional feature samples. The classification accuracy of ANN is the lowest among the three single classifiers, but there is no significant gap in accuracy between ANN and the other two classifiers. Therefore, the network structure and stability of ANN need to be strengthened. The small gap in the classification accuracy of the three single classifiers not only verifies the superiority of the selected single classifier, but also verifies the rationality of the unweighted voting method. After the ensemble of multi-classifier, the overall classification accuracy and Kappa coefficient are improved. The overall classification accuracy of the data in the four periods is above 90\%. In 1987, the classification accuracy of multi-classifier ensemble classification is $4.17 \%$ higher than that of $\mathrm{ANN}$, and the Kappa coefficient is increased by 0.051 , and the classification accuracy is improved most obviously. To sum up, the ensemble of multi-classifier can make the advantages of a single classifier complement each other to improve the classification accuracy.

\section{Quantitative Analysis of Ecosystem Area Change}

From the perspective of one-level classification, as shown in Fig. 3a), the area of natural ecosystem was

Table 2. Classification rules of ecosystem in water-land interaction area of Nansi Lake.

\begin{tabular}{|c|c|c|c|c|}
\hline $\begin{array}{c}\text { One-level } \\
\text { classification }\end{array}$ & $\begin{array}{c}\text { Two-level } \\
\text { classification }\end{array}$ & $\begin{array}{l}\text { Three-level } \\
\text { classification }\end{array}$ & Type of land & $\begin{array}{l}\text { Interpretation } \\
\text { features }\end{array}$ \\
\hline \multirow{4}{*}{$\begin{array}{c}\text { Natural } \\
\text { ecosystem }\end{array}$} & \multirow{2}{*}{$\begin{array}{l}\text { Terrestrial } \\
\text { ecosystem }\end{array}$} & Forest ecosystem & Woodland & $\begin{array}{l}\text { Dark green; mostly distributed on the periphery of } \\
\text { mountains, villages and water surface; highlighted in the } \\
\text { GREENNESS }\end{array}$ \\
\hline & & $\begin{array}{c}\text { Desert } \\
\text { ecosystem }\end{array}$ & $\begin{array}{l}\text { Wasteland, other } \\
\text { land }\end{array}$ & Brown; highlighted in NDBI and BRIGHTNESS \\
\hline & \multirow{2}{*}{$\begin{array}{c}\text { Water } \\
\text { ecosystem }\end{array}$} & $\begin{array}{l}\text { Freshwater } \\
\text { ecosystem }\end{array}$ & $\begin{array}{l}\text { Lakes, rivers, } \\
\text { reservoirs }\end{array}$ & $\begin{array}{l}\text { Dark blue or black; irregular in shape; obvious boundaries; } \\
\text { highlighted in MNDWI }\end{array}$ \\
\hline & & $\begin{array}{l}\text { Wetland } \\
\text { ecosystem }\end{array}$ & $\begin{array}{l}\text { Wetland (reed, } \\
\text { lotus field, etc.) }\end{array}$ & $\begin{array}{c}\text { Green; irregular shape; clustered, or scattered; mostly } \\
\text { distributed in the water boundary; highlighted in GREEN- } \\
\text { NESS }\end{array}$ \\
\hline \multirow{3}{*}{$\begin{array}{l}\text { Artificial } \\
\text { ecosystem }\end{array}$} & \multirow{2}{*}{$\begin{array}{l}\text { Farmland } \\
\text { ecosystem }\end{array}$} & $\begin{array}{c}\text { Dryland } \\
\text { ecosystem }\end{array}$ & Dry farmland & $\begin{array}{l}\text { Green; regular shape; mostly rectangular grid; clear tex- } \\
\text { ture, highlighted in GREENNESS }\end{array}$ \\
\hline & & $\begin{array}{l}\text { Paddy field } \\
\text { ecosystem }\end{array}$ & Paddy field & $\begin{array}{c}\text { Green; regular shape; mostly distributed in the areas near } \\
\text { rivers and lakes ; clear texture, highlighted in GREEN- } \\
\text { NESS and MNDWI }\end{array}$ \\
\hline & $\begin{array}{c}\text { Urban } \\
\text { ecosystem }\end{array}$ & Urban ecosystem & $\begin{array}{l}\text { Construction } \\
\text { land, road }\end{array}$ & $\begin{array}{l}\text { Bright white or bluish-white; clear borders; contiguously } \\
\text { distributed, highlighted in NDBI and GREENNESS }\end{array}$ \\
\hline
\end{tabular}

Note: "NDBI" is the abbreviation of "Normalized Difference Build-up Index". "MNDWI" is the abbreviation of "Modified Normalized Difference Water Index". "GREENNESS" and "BRIGHTNESS" are two components of "Kauth-Thomas Transformation". 
Table 3. Accuracy evaluation of ecosystem cover information extraction in Water-Land interaction area of Nansi Lake.

\begin{tabular}{|c|c|c|c|c|c|c|c|c|}
\hline \multirow{2}{*}{ Classification } & \multicolumn{2}{|c|}{1987} & \multicolumn{2}{c|}{1997} & \multicolumn{2}{c|}{2006} & \multicolumn{2}{c|}{2017} \\
\cline { 2 - 10 } & $\begin{array}{c}\text { Overall } \\
\text { accuracy }\end{array}$ & $\begin{array}{c}\text { Kappa } \\
\text { coefficient }\end{array}$ & $\begin{array}{c}\text { Overall } \\
\text { accuracy }\end{array}$ & $\begin{array}{c}\text { Kappa } \\
\text { coefficient }\end{array}$ & $\begin{array}{c}\text { Overall } \\
\text { accuracy }\end{array}$ & $\begin{array}{c}\text { Kappa } \\
\text { coefficient }\end{array}$ & $\begin{array}{c}\text { Overall } \\
\text { accuracy }\end{array}$ & $\begin{array}{c}\text { Kappa } \\
\text { coefficient }\end{array}$ \\
\hline SVM & $89.82 \%$ & 0.874 & $90.22 \%$ & 0.877 & $89.84 \%$ & 0.863 & $90.17 \%$ & 0.874 \\
\hline RFC & $89.54 \%$ & 0.871 & $90.13 \%$ & 0.877 & $87.71 \%$ & 0.834 & $89.51 \%$ & 0.866 \\
\hline ANN & $85.87 \%$ & 0.826 & $89.32 \%$ & 0.866 & $88.26 \%$ & 0.843 & $88.23 \%$ & 0.849 \\
\hline $\begin{array}{c}\text { Multi-classifier } \\
\text { ensemble classification }\end{array}$ & $90.04 \%$ & 0.877 & $90.42 \%$ & 0.880 & $90.05 \%$ & 0.866 & $90.65 \%$ & 0.880 \\
\hline
\end{tabular}

always larger than that of artificial ecosystem from 1987 to 2017, which showed that the study area had preserved the original appearance of natural ecology. The ecosystem area was relatively stable from 1987 to 1997, and fluctuated greatly from 1997 to 2017. In particular, there was an inflection point in the ecosystem structure of the water-land interaction area of Nansi Lake in 2006. From 1997 to 2006, the area of natural ecosystem increased by $199.603 \mathrm{~km}^{2}$, with an increase rate of $13.64 \%$, while the artificial ecosystem decreased by the same area. In 2006, the area of natural ecosystem was the maximum value of $1663.079 \mathrm{~km}^{2}$ in the past 30 years, while the artificial ecosystem area was the minimum value of $1071.428 \mathrm{~km}^{2}$. From 2006 to 2017 , the ecosystem structure of the study area had a trend before it was gradually restored.

From the perspective of two-level classification, as shown in Fig. 3b), the area of the four ecosystems
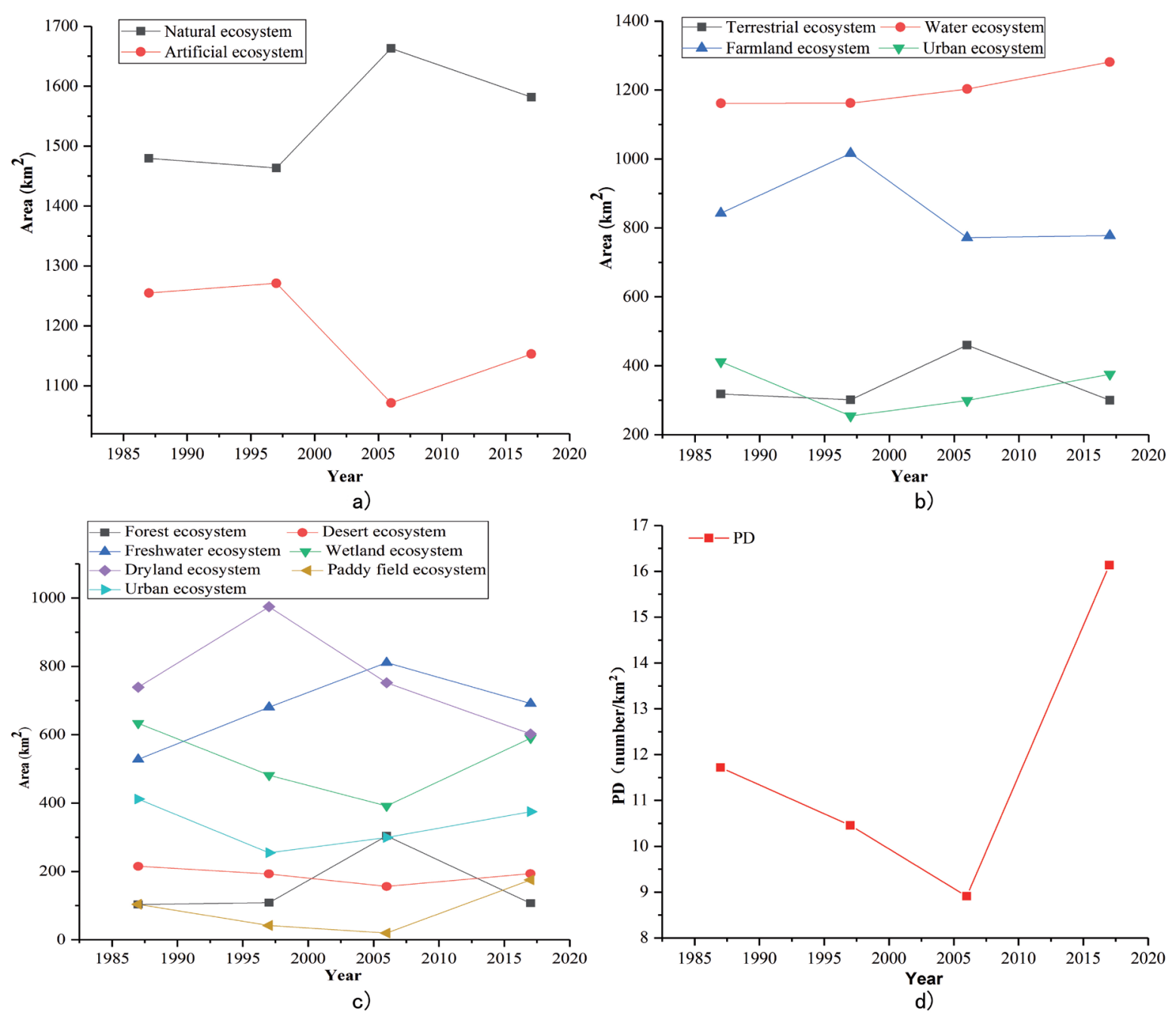

Fig. 3(a-c) Area and change trend of ecosystem in water-land interaction area of Nansi Lake (one-level, two-level, three-level classification) from 1987 to 2017 d) Change trend of patch density of ecosystem in water-land interaction area of Nansi Lake from 1987 to 2017. 
showed different trends from 1987 to 2017, which reflected the diversity characteristics of ecosystem changes. Water ecosystem was the largest ecosystem type with an increasing trend year by year. Its area was more than $1000 \mathrm{~km}^{2}$ from 1987 to 2017, accounting for more than $40 \%$. The second was the farmland ecosystem, which accounted for about $30 \%$ of the area. The area of terrestrial and urban ecosystems was smaller than that of the other two types of ecosystems, accounting for about $11 \%$ of the total area.

From the perspective of three-level classification, as shown in Fig. 3c), the ecosystem area of dryland, fresh water and wetland was relatively large from 1987 to 2017 , accounting for about $20 \%-30 \%$ of the total area of the study area respectively. In 1997, the dryland ecosystem area reached the maximum value of the third-level classification ecosystem area in the study time series, which was $974.463 \mathrm{~km}^{2}$, accounting for $35.64 \%$ of the total area. The ecosystem area of forest, paddy field and desert were small, with each type accounting for less than $10 \%$ of the total area. In addition, the turning points of other ecosystem areas appeared in 2006 except for dryland farmland ecosystem and urban ecosystem. It could be seen that the extreme reduction of precipitation in 2002 and the implementation of the South-to-North Water Diversion Project had a great impact on the ecosystem structure of the water-land interaction area of Nansi Lake.
Fig. 3d) shows the change of PD in the study time series, which also showed an obvious inflection point in 2006. From 1987 to 2006, the PD showed a continuous decreasing trend, with a decreasing rate of $23.97 \%$. In 2006, the degree of ecosystem fragmentation was the lowest and the stability of ecosystem structure was the strongest. The PD was only 8.9094, which was the lowest during the study period. At this time, the area of the natural ecosystem also reached the maximum value of the research interval (Fig. 3a), indicating that the increase of the natural ecosystem is conducive to strengthening the stability of the ecosystem. From 2006 to 2017 , the PD of ecosystem increased by $81.10 \%$, and its value was 16.1345 , which was the highest value in the study time interval. During this period, the degree of ecosystem fragmentation in the study area was high, and the structural stability was weakened.

\section{Quantitative Analysis of Ecosystem Transfer Change}

From the perspective of two-level classification, the transfer matrix of ecosystem types in the study time series is shown in Tables 4,5 and 6. The area of ecosystem transfer in the three study areas were $1147.729 \mathrm{~km}^{2}, 1025.214 \mathrm{~km}^{2}$ and $1265.025 \mathrm{~km}^{2}$, accounting for $41.97 \%, 37.49 \%$ and $46.26 \%$ of the total area, respectively. The larger transfer area reflected the unstable factors in the ecosystem structure, and also

Table 4. Ecosystem transfer matrix from 1987 to 1997 (unit: km²).

\begin{tabular}{|c|c|c|c|c|c|}
\hline 1987 & Terrestrial ecosystem & Water ecosystem & Farmland ecosystem & Urban ecosystem & Transferred area \\
\hline Terrestrial ecosystem & $\begin{array}{c}90.230 \\
(26.746)\end{array}$ & 33.721 & 115.847 & 51.681 & 227.993 \\
\hline Water ecosystem & 25.521 & $\begin{array}{c}746.871 \\
(240.077)\end{array}$ & 121.356 & 27.671 & 414.625 \\
\hline Farmland ecosystem & 80.668 & 74.786 & $\begin{array}{c}616.845 \\
(28.146)\end{array}$ & 42.440 & 226.041 \\
\hline Urban ecosystem & 78.221 & 66.635 & 134.213 & 132.833 & 279.070 \\
\hline Transferred area & 211.156 & 415.219 & 399.562 & 121.792 & 1147.729 \\
\hline
\end{tabular}

Table 5. Ecosystem transfer matrix from 1997 to 2006 (unit: km²).

\begin{tabular}{|c|c|c|c|c|c|}
\hline 1997 & Terrestrial ecosystem & Water ecosystem & Farmland ecosystem & Urban ecosystem & Transferred area \\
\hline Terrestrial ecosystem & $\begin{array}{c}111.991 \\
(55.797)\end{array}$ & 15.271 & 57.975 & 60.356 & 189.399 \\
\hline Water ecosystem & 24.919 & $\begin{array}{c}818.368 \\
(253.822)\end{array}$ & 42.456 & 22.525 & 343.722 \\
\hline Farmland ecosystem & 198.841 & 97.216 & $\begin{array}{c}637.606 \\
(7.668)\end{array}$ & 75.077 & 378.802 \\
\hline Urban ecosystem & 68.623 & 18.235 & 26.433 & 141.333 & 113.291 \\
\hline Transferred area & 348.18 & 384.544 & 134.532 & 157.958 & 1025.214 \\
\hline
\end{tabular}


Table 6. Ecosystem transfer matrix from 2006 to 2017 (unit: $\mathrm{km}^{2}$ ).

\begin{tabular}{|c|c|c|c|c|c|}
\hline 2006 & Terrestrial ecosystem & Water ecosystem & Farmland ecosystem & Urban ecosystem & Transferred area \\
\hline Terrestrial ecosystem & $\begin{array}{c}98.035 \\
(55.024)\end{array}$ & 79.641 & 137.038 & 90.432 & 362.135 \\
\hline Water ecosystem & 37.856 & $\begin{array}{c}776.885 \\
(279.359)\end{array}$ & 86.508 & 22.303 & 426.026 \\
\hline Farmland ecosystem & 75.186 & 105.769 & $\begin{array}{c}413.505 \\
(96.333)\end{array}$ & 81.346 & 358.634 \\
\hline Urban ecosystem & 34.162 & 39.635 & 44.433 & 181.060 & 118.230 \\
\hline Transferred area & 202.228 & 504.404 & 364.312 & 194.081 & 1265.025 \\
\hline
\end{tabular}

Note: For Table 4- Table 6, the original data of ecosystem transfer matrix in the study area is completed on the basis of three-level classification. For the convenience of analysis, the data are combined and displayed from the perspective of two-level ecosystem types. Therefore, there is a transfer between the same secondary ecosystem types in the table, which is actually the transfer between the three-level classification systems belonging to the same two-level classification system. This part of the transfer data is shown in brackets.

affected the fragmentation degree of regional landscape. Compared with Fig. 3d), it was found that the change trend of transfer area was similar to that of PD. When the transfer area became smaller, the PD became smaller, and the degree of landscape fragmentation was lower, such as 1987-1997 and 1997-2006. On the contrary, the degree of landscape fragmentation was high, such as 2006-2017. From the point of view of transfer types, the incoming and outgoing areas of water ecosystems were the largest in 1987-1997 and 2006-2017, which was mainly the mutual transfer between freshwater ecosystem and wetland ecosystem, and this phenomenon reflected the instability at the junction of water and land. During the study period from 1997 to 2006, in addition to the water ecosystem, the transfer area of the farmland ecosystem and the transfer area of the terrestrial ecosystem were also larger. The study found that the area of dryland farmland ecosystem transferred into forest ecosystem was $157.907 \mathrm{~km}^{2}$, accounting for $41.69 \%$ of the farmland transferred out area and $45.35 \%$ of the land transferred in area in 1997-2006, which was mainly affected by the national call for "returning farmland to forest".

\section{Spatial Distribution of Ecosystem Structure}

From different perspectives, the spatial distribution characteristics of ecosystem structure in the water-land interaction area of Nansi Lake is found. As shown in Fig. 4a), taking the spatial distribution of three-level classification ecosystem structure in 1997 as an example, the ecosystem structure of the study area appeared the characteristics of "ring" distribution, which was divided into three rings from the inside to the outside. The first ring located at center position of the study area, and its ecosystem mainly included freshwater ecosystem, which was mainly the water area of Weishan Lake, Zhaoyang Lake, Dushan Lake and Nanyang Lake. The second ring was the wetland ecosystem, which mainly included the wetland areas at the boundary of water and land, such as reed, lotus field, etc. The most outer ring was dominated by dryland farmland ecosystem, and other ecosystems were cross distributed. The special location of water-land interaction in the study area was the main reason for the formation of the "ring" feature of the ecosystem. In the study time series, from the perspective of two-level classification, the transfer distribution among ecosystem types also had the spatial characteristics of "ring". As shown in Fig. 4b), taking the spatial distribution of two-level classification ecosystem transfer from 1997 to 2006 as an example, it was divided into two rings from the inside to the outside. The first ring mainly included the lake water area in the center of the study area and its ecosystem type was freshwater ecosystem. There was no obvious transfer of ecosystem types in the first ring. The second ring mainly included the water-land junction and the land part, which was an obvious and complex area of ecosystem transformation. The transition between freshwater and wetland ecosystems and other types of ecosystems was more in the water-land interface. Land area involved the pairwise transformation of all ecosystem types in the study area. There were more human activities in the water land interface and land area, but it had little intervention in the water area. Therefore, the distribution and transfer of ecosystem types in the water land interface and land area were more complex.

\section{Driving Factors of Ecosystem Structure Change}

Based on the comprehensive analysis of hydrology, temperature, precipitation and policy evolution of the study area in recent 30 years, it was found that human activities, climate change and ecosystem self-regulation were the main driving factors for the evolution of ecosystem structure in the water-land interaction area of Nansi Lake. 

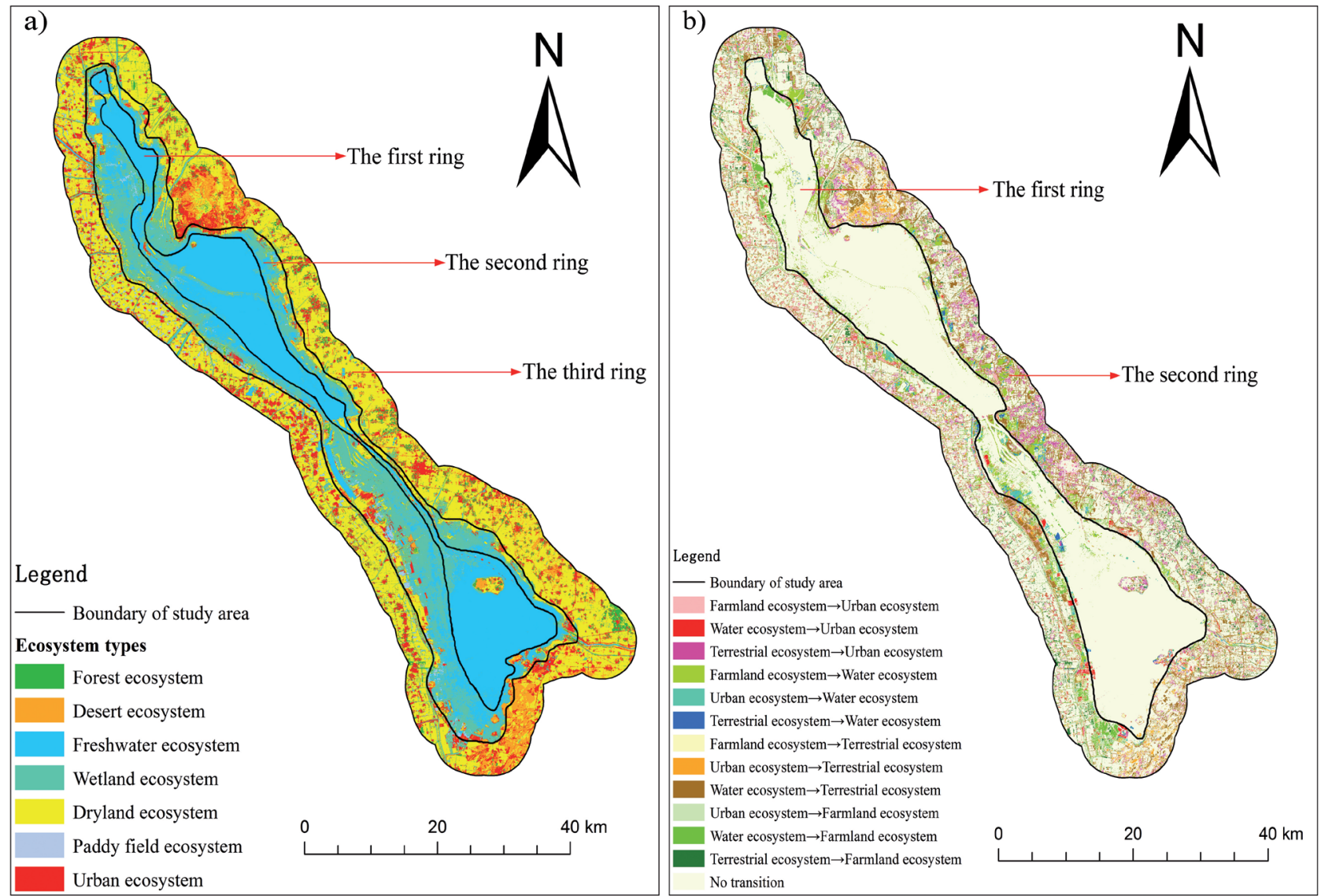

Fig.4. a) Distribution map of ecosystem in water-land interaction area of Nansi Lake in 1997 (one-level classification perspective) b) Transformation map of ecosystem in water-land interaction area of Nansi Lake type from 1997 to 2006 (two-level classification perspective).

Human activities under the intervention of China's national policies were the primary driving factors for the evolution of ecosystem structure in the study area [15]. Firstly, the implementation of the eastern route of the South-to-North Water Diversion Project had a great impact on the ecosystem structure of the study area [34]. Since the symposium on the preliminary work of the South-to-North Water Diversion Project was held in Beijing in 2000, the management department had actively carried out relevant preparatory work, which including lake desilting, returning farmland to lake, afforestation and so on, to ensure the water area of Nansi Lake [52]. Therefore, although the study area suffered from drought disasters in 2002 [21], the area of water ecosystem increased slightly from 1997 to 2006 (Fig. 3b). Second, the impact of the national "Returning Farmland to Forest" project was also more significant. Since 2002, the study area stopped farming step by step to restore forest vegetation and increase the area of forest land [32]. Therefore, the area of farmland conversion to woodland ecosystem was more than other years in 1997-2006. Third, the establishment of "nature reserves" and delimitation of "ecological protection red line" and other measures played an important role in the protection of the ecosystem. In addition, policies concerning reform and opening up, water conservancy projects and tourism development had certain influence on ecological system structure of research area $[7,8$, 52].

The change of climate and environment directly or indirectly affected the change of ecosystem structure $[5,37]$. The study area with uneven annual precipitation and strong seasonality is located in the warm temperate monsoon climate, which is prone to drought and flood disasters. In the study time series, the study area suffered from serious drought disaster in 2002. The precipitation from June to September was 225 $\mathrm{mm}$, which was more than $50 \%$ lower than that in the same period of the year. The decrease of precipitation not only affected the water consumption for industry, agriculture, animal husbandry, forestry and domestic use, but also significantly reduced the area of wetland and paddy field ecosystem (Fig. 3c) from 1997 to 2006. After that, with the normalization of precipitation, the area of wetland and paddy field ecosystem increased gradually.

The self-regulation of ecosystem also affected the area change and transfer of each ecosystem to a certain extent [53]. Self-regulation is the selfprotection, improvement and perfection of ecosystem in order to stabilize its own state. From 1987 to 1997, the natural and artificial ecosystems of Nansi Lake 
were stable as a whole (Fig. 3a). The slight changes were reflected in the self-regulation of the ecosystem.

\section{Conclusions}

The ecosystem cover information of the water-land interaction area of Nansi Lake was extracted by multiclassifier ensemble method, and the ecosystem structure and driving factors were analyzed. The specific conclusions were as follows:

(1) The paper proposed an ensemble method for extracting remote sensing information by integrating SVM, RFC and ANN with unweighted voting method. This method improved the overall accuracy and Kappa coefficient of ecosystem coverage information extraction in the water-land interaction area of Nansi Lake, and the overall classification accuracy of the four images exceeded $90 \%$. In 1987, the classification accuracy of multi-classifier ensemble classification was $4.17 \%$ higher than that of $\mathrm{ANN}$, and the Kappa coefficient was increased by 0.051 , and the classification accuracy was improved most obviously. To sum up, the integration method can be extended to land use cover, buildings, roads and other types of remote sensing information extraction, which has reference significance for how to improve the accuracy of remote sensing information extraction.

(2) From 1987 to 2017, the area changes of various ecosystems showed a variety of trends, and the inflection point appeared in 2006. There was a large area transfer phenomenon among different ecosystem types in the three study periods, which were $1147.729 \mathrm{~km}^{2}$, $1025.214 \mathrm{~km}^{2}$ and $1265.025 \mathrm{~km}^{2}$, respectively. Among them, water ecosystem was the largest ecosystem type transferred into and out area. The distribution of ecosystem structure and transfer in the study area showed the characteristics of "ring", and the ecosystem distribution and transformation in the land and water boundary area were relatively complex.

(3) Human activities under Chinese policy intervention were the primary driving factors of ecological system structure change in the study area. Climate change, especially the occurrence of drought and flood disasters, had a direct or indirect impact on the ecosystem structure. Moreover, the self-regulation of ecosystem also caused the fine adjustment of ecosystem structure.

(4) We should protect and stabilize the ecosystem structure of the water-land interaction area of Nansi Lake to give full play to its ecological service and economic development function by improving the public awareness of environmental protection, improving the ecological protection laws and policies, and establishing the "Nansi Lake Ecosystem Supervision and Evaluation System".

In this study, only three single classifiers based on machine learning were selected for classifier ensemble.
It is worth exploring to try to integrate classifiers with more different classification ideas. Meanwhile, in terms of the analysis of ecosystem structure evolution in the water-land interaction area of Nansi Lake, quantitative study of ecological threshold and prediction of ecosystem structure will also be the direction of further research.

\section{Acknowledgements}

This research was supported by National Natural Science Foundation of China (72033005) and Ministry of Land and Resources of the People's Republic of China (201511010).

\section{Conflict of Interest}

The authors declare no conflict of interest.

\section{References}

1. BANERJEE O., CROSSMAN N., VARGAS R., BRANDER L., VERBURG P., CICOWIEZ M., HAUCK J., MCKENZIE E. Global socio-economic impacts of changes in natural capital and ecosystem services: State of play and new modeling approaches. Ecosystem Services, 46, 101202, 2020.

2. JORGENSEN S.E. Integration of Ecosystem Theories: A Pattern; Kluwer Academic Publishers: Dordrecht, the Netherlands, 1-46, 1992 [In English].

3. PRINGLE R.M., DOAK D.F., BRODY A.K., JOCQUE R., PALMER T.M. Spatial pattern enhances ecosystem functioning in an African savanna. PLoS Biology, 8, (5), e1000377, 2010.

4. REID A.J., CARLSON A.K., CREED I.F., ELIASON E.J., GELL P.A., JOHNSON P.T.J., KIDD K.A., MACCORMACK T.J., OLDEN J.D., ORMEROD S.J., SMOL J.P., TAYLOR W.W., TOCKNER K., VERMAIRE J.C., DUDGEON D., COOKE S.J. Emerging threats and persistent conservation challenges for freshwater biodiversity. Biological Reviews, 94 (3), 849, 2018.

5. CM BROCK T., HP ARTS G., MALTBY L., VAN DEN BRINK P.J. Aquatic risks of pesticides, ecological protection goals, and common aims in European Union legislation. Integrated Environmental Assessment and Management, 2, 20, 2006.

6. PREISNER M., NEVEROVA-DZIOPAK E., KOWALEWSKI Z. An analytical review of different approaches to wastewater discharge standards with particular emphasis on nutrients. Environmental Management, 66 (4), 694, 2020.

7. BAI Y., JIANG B., WANG M., LI H., ALATALO J.M., HUANG S. New ecological redline policy (ERP) to secure ecosystem services in China. Land Use Policy, 55, 348, 2016.

8. ZHANG L., WANG X., ZHANG J.J., OUYANG Z.Y., CHAN S., CROSBY M., WATKINS D., MARTINEZ J., SU L.Y., YU Y.T., SZABO J., CAO L., FOX A.D. Formulating a list of sites of waterbird conservation significance to contribute to China's Ecological Protection 
Red Line. Bird Conservation International, 27 (2), 153, 2017.

9. WU X., LIU S., CHENG F., HOU X., ZHANG Y., DONG S., LIU G. A regional strategy for ecological sustainability: A case study in Southwest China. Science of the Total Environment, 616-617, 1224, 2018.

10. LI J., LIANG J.X., WU Y., YIN S.Q., YANG Z., HU Z.Q. Quantitative evaluation of ecological cumulative effect in mining area using a pixel-based time series model of ecosystem service value. Ecological Indicators, 120, 106873, 2021.

11. ZHU D.Y., CHEN T., ZHEN N., NIU R.Q. Monitoring the effects of open-pit mining on the eco-environment using a moving window-based remote sensing ecological index. Environmental Science and Pollution Research, 27 (13), 15716, 2020.

12. XIAO W., ZHANG W.K., YE Y.M., LV X.J., YANG W.F. Is underground coal mining causing land degradation and significantly damaging ecosystems in semi-arid areas? A study from an Ecological Capital perspective. Land Degradation \& Development, 31 (15), 1969, 2020.

13. DING Q., WANG L., FU M., HUANG N. An integrated system for rapid assessment of ecological quality based on remote sensing data. Environ Environmental Science and Pollution Research International, 27 (26), 32779, 2020.

14. LI H.Y., MAO D.H., LI X.Y., WANG Z.M., WANG C.Z. Monitoring 40-year lake area changes of the Qaidam Basin, Tibetan Plateau, using Landsat time series. Remote Sensing, 11 (3), 343, 2019.

15. ZHANG F., ZHANG J.Q., WU R., MA Q.Y., YANG J. Ecosystem health assessment based on DPSIRM framework and health distance model in Nansi Lake, China. Stochastic Environmental Research and Risk Assessment, 30 (4), 1235, 2016.

16. GAO J.B. Editorial for the special issue "ecosystem services with remote sensing“. Remote Sensing, 12 (14), 2191, 2020

17. BARON J., HILL D.J. Monitoring grassland invasion by spotted knapweed (Centaurea maculosa) with RPASacquired multispectral imagery. Remote Sensing of Environment, 249, 2020.

18. LELONG C.C.D., TSHINGOMBA U.K., SOTI V. Assessing Worldview-3 multispectral imaging abilities to map the tree diversity in semi-arid parklands. International Journal of Applied Earth Observation and Geoinformation, 93, 102211, 2020.

19. LUO Z.L., SHAO Q.X., ZUO Q.T., CUI Y.K. Impact of land use and urbanization on river water quality and ecology in a dam dominated basin. Journal of Hydrology, 584, 124655, 2020.

20. TALUKDAR S., SINGHA P., MAHATO S., SHAHFAHAD, PAL S., LIOU Y.A., RAHMAN A. Land-use land-cover classification by machine learning classifiers for satellite observations-a review. Remote Sensing, 12 (7), 2020.

21. MENG L.R., DONG J.H. "LUCC and ecosystem service value assessment for wetlands: a case study in Nansi Lake, China. Water, 11 (8), 2019.

22. WANG X.X., GAO X.W., ZHANG Y.Z., FEI X.Y., CHEN Z., WANG J., ZHANG Y.Y., LU X., ZHAO H.M. Landcover classification of coastal wetlands using the RF algorithm for Worldview-2 and Landsat 8 images. Remote Sensing, 11 (16), 2019.

23. XIU Y.C., LIU W.B., YANG W.J. An improved rotation forest for multi-feature remote-sensing imagery classification. Remote Sensing, 9 (11), 1205, 2017.
24. LIU J.T., LIU C.T., FENG Q.L., MA Y. Subpixel impervious surface estimation in the Nansi Lake Basin using random forest regression combined with GF-5 hyperspectral data. Journal of Applied Remote Sensing, 14 (3), 2020.

25. KNAUER U., VON REKOWSKI C.S., STECKLINA M., KROKOTSCH T., MINH T.P., HAUFFE V., KILIAS D., EHRHARDT I., SAGISCHEWSKI H., CHMARA S., SEIFFERT U. Tree species classification based on hybrid ensembles of a convolutional neural network (CNN) and random forest classifiers. Remote Sensing, 11 (23), 2019.

26. ZHANG M., LI C., YANG L.Y., DING S.M., MA X., ZHANG Y., ZHAO T.T. Application of DGT/DIFS combined with BCR to assess the mobility and release risk of heavy metals in the sediments of Nansi Lake, China. Environmental Geochemistry and Health, 42 (11), 3765, 2020.

27. MA X., LI C., YANG L.Y., DING S.M., ZHANG M., ZHANG Y., ZHAO T.T. Evaluating the mobility and labile of As and $\mathrm{Sb}$ using diffusive gradients in thin-films (DGT) in the sediments of Nansi Lake, China. Science of the Total Environment, 713, 2020.

28. GUO H.J., YANG L.Y., HAN X.M., DAI J.R., PANG X.G., REN M.Y., ZHANG W. Distribution characteristics of heavy metals in surface soils from the western area of Nansi Lake, China. Environmental Monitoring and Assessment, 191 (5), 2019.

29. ZHANG W., CAO F.F., YANG L.Y., DAI J.R., PANG X.G. Distribution, fractionation and risk assessment of mercury in surficial sediments of Nansi Lake, China. Environmental Geochemistry and Health, 40 (1), 115, 2018.

30. CAO Q.Q., SONG Y., ZHANG Y.R., WANG R.Q., LIU J. Risk analysis on heavy metal contamination in sediments of rivers flowing into Nansi Lake. Environmental Science and Pollution Research, 24 (35), 26910, 2017.

31. REN M.Y., YANG L.Y., WANG L.F., HAN X.M., DAI J.R., PANG X.G. Spatial trends and pollution assessment for mercury in the surface soils of the Nansi Lake catchment, China. Environmental Science and Pollution Research, 25 (3), 2417, 2018

32. WANG F., ZHANG S.L., HOU H.P., YANG Y.J., GONG Y.L. Assessing the changes of ecosystem services in the Nansi Lake wetland, China. Water, 11 (4), 788, 2019.

33. JING Y.D., CHANG Y.Q., CHENG X.Y., WANG D. Land-use changes and ecosystem services under different scenarios in Nansi Lake Basin, China. Environmental Monitoring and Assessment, 193 (1), 2021.

34. DIVYA K.R., ZHAO S.S., CHEN Y.S., CHENG F. ZHANG L., QIN J., ARUNJITH T.S., BJORN V.S., XIE S.G. A comparison of zooplankton assemblages in Nansi Lake and Hongze Lake, potential influences of the East Route of the South-to-North Water Transfer Project, China. Journal of Oceanology and Limnology, 2020.

35. LIU Y., YANG L.Y., JIANG W. Qualitative and quantitative analysis of the relationship between water pollution and economic growth: a case study in Nansi Lake catchment, China. Environmental Science and Pollution Research, 27 (4), 4008, 2020.

36. ZHANG G.D., LIU X.H., LU S.Y., ZHANG J.P., WANG W.L. Occurrence of typical antibiotics in Nansi Lake's inflowing rivers and antibiotic source contribution to Nansi Lake based on principal component analysis-multiple linear regression model. Chemosphere, 242, 2020.

37. GE X.L., LIU J., WANG R.Q. Effects of flooding on the germination of seed banks in the Nansi Lake wetlands, China. Journal of Freshwater Ecology, 28 (2), 225, 2013. 
38. TOOSI N.B., SOFFIANIAN A.R., FAKHERAN S., POURMANAFI S., GINZLER C., WASER L.T. Land cover classification in mangrove ecosystems based on VHR satellite data and machine learning-an upscaling approach. Remote Sensing, 12 (17), 2020.

39. MELGANI F., BRUZZONE L. Classification of hyperspectral remote sensing images with support vector machines. Ieee Transactions on Geoscience and Remote Sensing, 42 (8), 1778, 2004.

40. ZHANG C., WANG T.J., ATKINSON P.M., PAN X., LI H.P. A novel multi-parameter support vector machine for image classification. International Journal of Remote Sensing, 36 (7), 1890, 2015.

41. RODRIGUEZ-GALIANO V.F., CHICA-OLMO M., ABARCA-HERNANDEZ F., ATKINSON P.M., JEGANATHAN C. Random Forest classification of Mediterranean land cover using multi-seasonal imagery and multi-seasonal texture. Remote Sensing of Environment, 121, 93, 2012.

42. PATEL N., MUKHERJEE R. Extraction of impervious features from spectral indices using artificial neural network. Arabian Journal of Geosciences, 8 (6), 3729, 2015.

43. DU P.J., XIA J.S., ZHANG W., TAN K., LIU Y., LIU S.C. Multiple classifier system for remote sensing image classification: a review. Sensors, 12 (4), 4764, 2012.

44. POURDARBANI R., SABZI S., HERNANDEZHERNANDEZ M., HERNANDEZ-HERNANDEZ J.L., GARCIA-MATEOS G., KALANTARI D., MOLINAMARTINEZ J.M. Comparison of different classifiers and the majority voting rule for the detection of plum fruits in garden conditions. Remote Sensing, 11 (21), 2019.

45. TAN K., ZHANG Y.S., WANG X., CHEN Y. Object-based change detection using multiple classifiers and multi-scale uncertainty analysis. Remote Sensing, 11 (3), 2019.
46. KAWAGUCHI S., NISHII R. Hyperspectral image classification by bootstrap AdaBoost with random decision stumps. Ieee Transactions on Geoscience and Remote Sensing, 45 (11), 3845, 2007.

47. ZHANG M., DU H.Q., MAO F.J., ZHOU G.M., LI X.J., DONG L.F., ZHENG J.L., ZHU D.E., LIU H., HUANG Z.H., HE S.B. Spatiotemporal evolution of urban expansion using Landsat time series data and assessment of its influences on forestss. ISPRS International Journal of Geo-Information, 9 (2), 64, 2020.

48. YU H.C., BIAN Z.F., MU S.G., YUAN J.F., CHEN F. Effects of climate change on land cover change and vegetation dynamics in Xinjiang, China. International Journal of Environmental Research and Public Health, 17, (13), 4865, 2020.

49. LEE Y.C., AHERN J., YEH C.T. Ecosystem services in pen-urban landscapes: The effects of agricultural landscape change on ecosystem services in Taiwan's western coastal plain. Landscape and Urban Planning, 139, 137, 2015.

50. DADASHPOOR H., AZIZI P., MOGHADASI M. Land use change, urbanization, and change in landscape pattern in a metropolitan area. Science of the Total Environment, 655, 707, 2019.

51. SHI F.N., LIU S.L., SUN Y.X., AN Y., ZHAO S., LIU Y.X., LI M.Q. Ecological network construction of the heterogeneous agro-pastoral areas in the upper Yellow River basin. Agriculture Ecosystems \& Environment, 302, 2020.

52. ZHANG Q.F. The south-to-north water transfer project of China environmental implications and monitoring strategy. Journal of the American Water Resources Association, 45 (5), 1238, 2009

53. FUHRER E. Forest functions, ecosystem stability and management. Forest Ecology and Management, 132 (1), $29,2000$. 